\title{
Satellite image analysis of a huge landslide at Yi Gong, Tibet, China
}

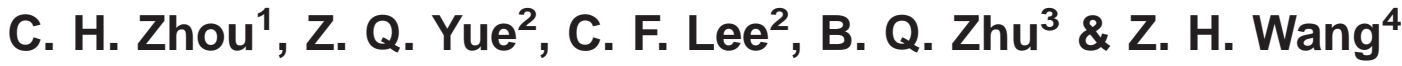 \\ ${ }^{1}$ State Key Laboratory of Resources \& Environmental Information System, The Chinese Academy of Sciences, \\ Beijing, China \\ ${ }^{2}$ Department of Civil Engineering, The University of Hong Kong, Hong Kong, China \\ ${ }^{3}$ Institute of Remote Sensing Application, The Chinese Academy of Sciences, Beijing, China \\ ${ }^{4}$ Remote Sensing Center, Ministry of Land and Resources of China, Beijing, China
}

At about 8 pm in the evening of Sunday 9 April 2000, a huge landslide occurred in the Yi Gong district, Tibet, China (Fig. 1). A gigantic volume of soil and rock slipped from the upper hillside at more than $5500 \mathrm{mPD}$ (metres above the Principal Datum, i.e, the Yellow Sea Level) along the Zamu gully, down to the Yi Gong River at about $2000 \mathrm{mPD}$, as shown in the site photos, a \& b in Figure 2 respectively. It travelled about $8 \mathrm{~km}$ and lasted about 10 minutes. The landslide debris was composed of snow, glacial ice, trees, soil and rock (marble, slate and granite). It destroyed a $2.5 \mathrm{~km}$ long section of the highway connecting Qinghai province to Tibet, blocked the Yi Gong River at the toe of the slope, and resulted in the flooding of several villages. This landslide is estimated to have a volume of $300000000 \mathrm{~m}^{3}$ and is thus one of the largest landslides recorded in the world.

Immediately after the landslide, the central and provincial governments and other relevant organizations carried out investigations of the landslide and urgent remedial works. This paper presents a satellite image analysis of the landslide and its consequences.

Satellite images have been used in landslide investigation since the mid-70s when Landsat MSS was launched. Examples of using satellite images to investigate landslides and to identify ground movements can be found in the publications by McDonald \& Grubbs (1975) and Manotvani et al. (1996).

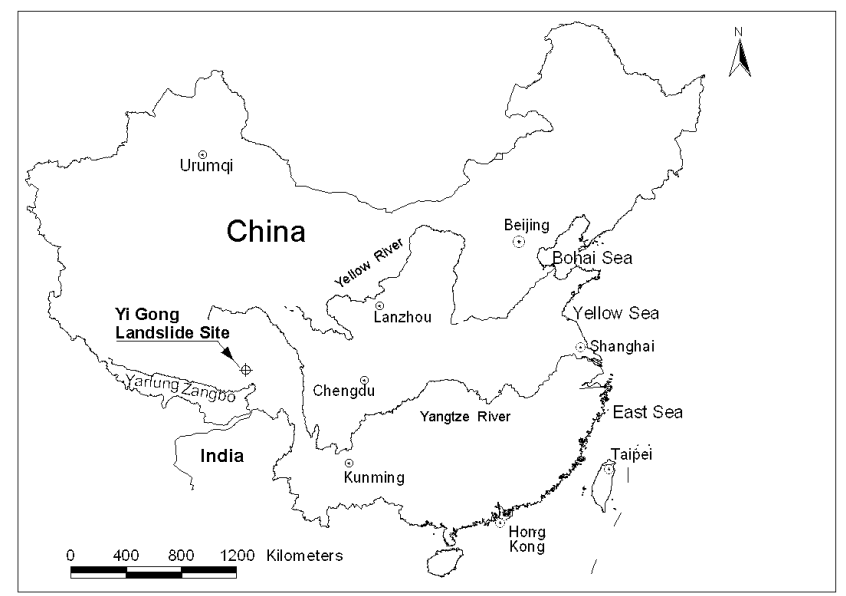

Fig. 1. Location plan of the Yi Gong Landslide of 9 April 2000, Yi Gong, Tibet, China.
The satellite images and remote sensing data used in the present analysis include the TM (Thematic Mapper) images from the USA Landsat 5 on 28 November 1999, the remote sensing data from China-Brazil Environmental and Resource Satellite (CBRS) No. 1 on 13 April and 9 May 2000, and the remote sensing data from the French SPOT Satellite on 4 and 9 May and 16 June 2000. Table 1 shows the details of the six images used in the analysis.

Topographic maps at 1:100 000 scale of Yi Gong district are used in the digital image processing of the satellite sensing data for geometric rectification and unification. Thus, satellite images with normal projection and the same geometric coordinate system were obtained for the analysis.

\section{Site conditions before the landslide}

The Yi Gong region is located on the Tibetan Plateau, adjacent to the northeastern corner of the India Tectonic Plate (Fig. 1). This region has a complex tectonic structure and active neo-tectonic movements. The solid geology in the northern region of the Yi Gong River is dominated by Jurassic-Cretaceous sedimentary rocks while the solid geology in the southern region of the $\mathrm{Yi}$ Gong River is dominated by Carboniferous-Permian sedimentary rocks (Xu et al. 1982). Granite and granitediorite also outcrop within the two groups of sedimentary rocks. The sedimentary rocks are mainly marble and slate. The marble, slate and granite have been weathered with different weathering depths and extent.

The Yi Gong landslide is located at the Zamu gully in the mountains NE of the Lower Yi Gong River. The Yi Gong River is situated in the lower mountainous region south of the well known Nian-Qing-Tang-Gu-La Mountain in eastern Tibet. It is one of the main branches of the Yarlung Zangbo River, joining it at the sharp bend as shown in Figure 1.

The geomorphological and ground surface conditions at the landslide site before 9 April 2000 have been studied by incorporating the TM images received by the USA Landsat-5 with the topographic maps at 1:100 000 scale of Yi Gong district. One of the TM 

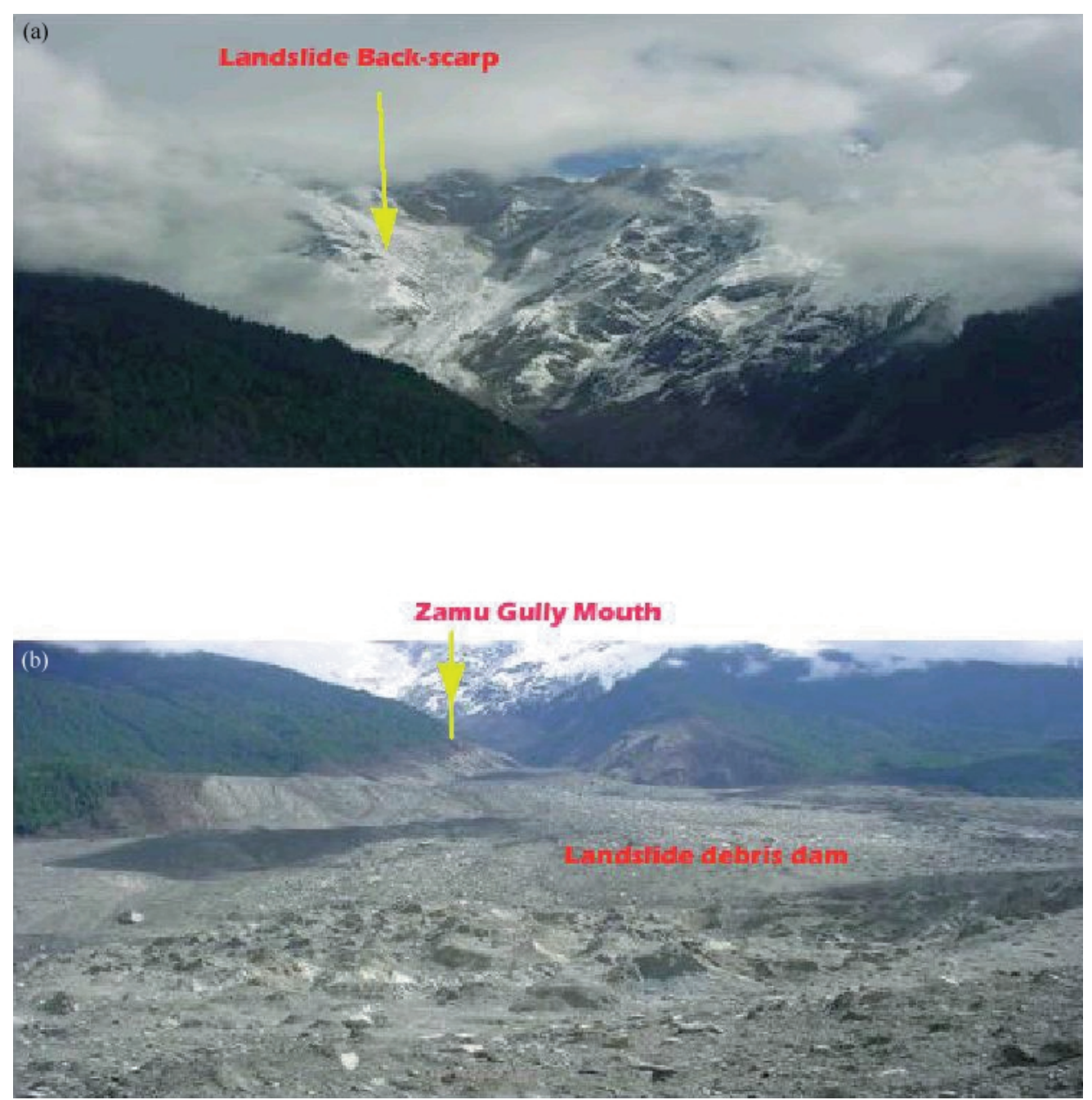

Fig. 2. Site photographs illustrating the Yi Gong Landslide: (a) The Zone I (Landslide back-scar) and (b) Zone III (the Zamu gully mouth and the landslide debris dam).

Table 1. Details of the satellite images used in the Yi Gong landslide investigation

\begin{tabular}{lccc}
\hline Satellite & USA Landsat 5 & French SPOT & CBRS No. 1 \\
\hline No. of bands & 7 & 3 & 5 \\
Spatial resolution (m) & 30 & 20 & 20 \\
Temporal resolution (day) & 18 & 26 & 26 \\
Swath width (km) & 185 & $2 \times 60$ & 113 \\
Capture date & 28 Nov. 1998 & 4, 9 May and 16 June 2000 & 13 April and 9 May 2000 \\
\hline
\end{tabular}

images received on 28 November 1998 is illustrated in Figure 3.

The geomorphological condition of Yi Gong district is characterized by very high mountains and very deep and steep valleys and gullies. These deep and steep valleys and gullies were formed by glaciation, river erosion and debris flows on the Tibetan Plateau. The depth of erosion is about 2000 to $4000 \mathrm{~m}$. The mountain ridges are of heights between 4000 and $6255 \mathrm{mPD}$ and are covered by snow and glacial ice. The majority of the mountain surfaces below about 4000 mPD are covered by forest. Farmlands and villages are distributed on the alluvial fans along the foot of the mountains.

The middle stretch of the Yi Gong River is 2.5 to $3.5 \mathrm{~km}$ wide and is locally called the Yi Gong Lake. The lake was not full on 28 November 1998 and showed several braided stream channels. The inlet and outlet levels of the Yi Gong Lake were about 2230 and $2190 \mathrm{mPD}$ respectively. The lake basin occupied an area of $26 \mathrm{~km}^{2}$ in plan. 


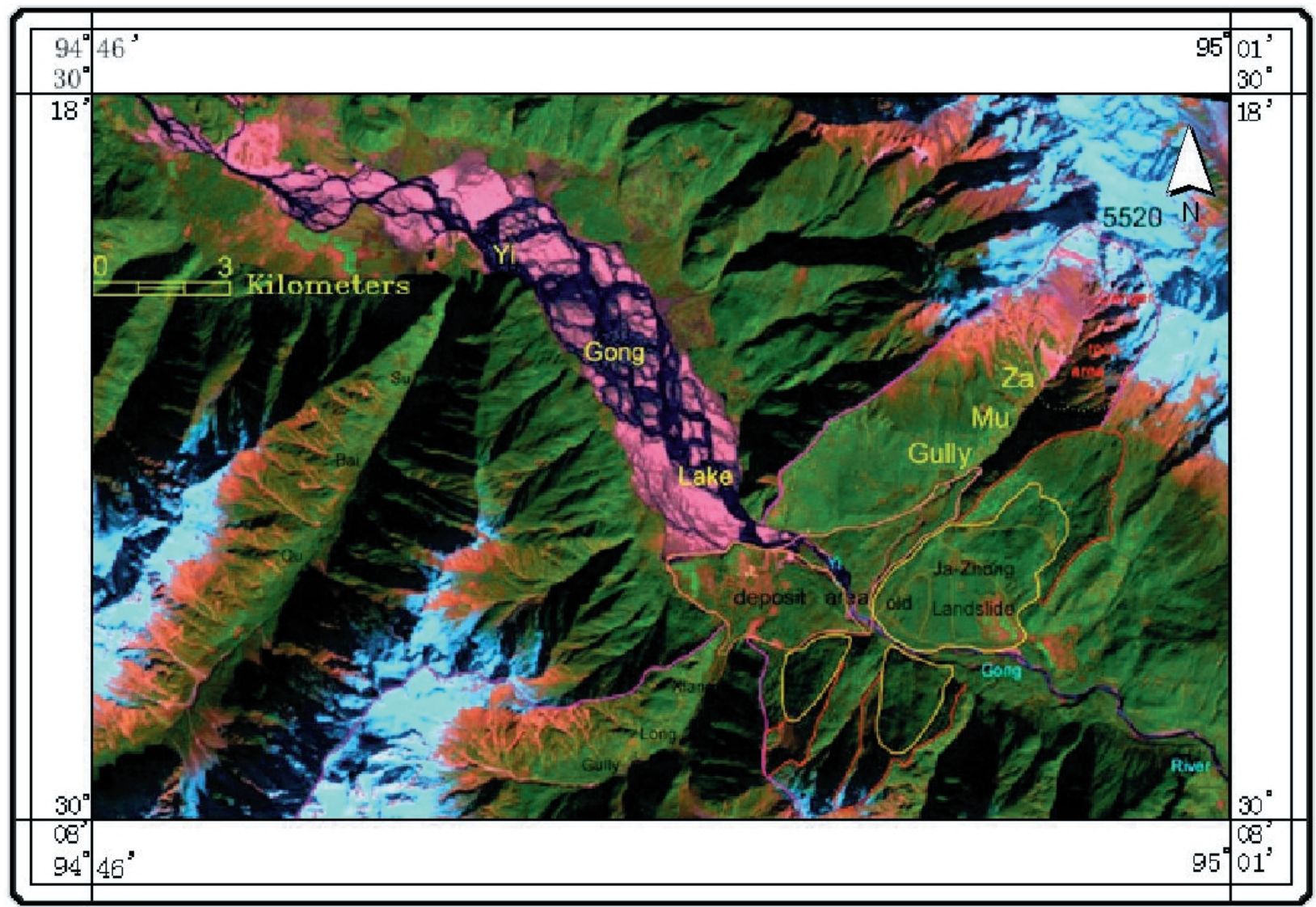

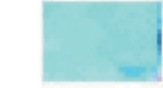

Ice and Snow

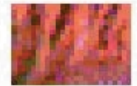

Naked Rock

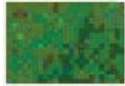

Forest Land

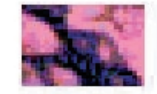

River Bed

Fig. 3. The TM image received on the 28 November 1998 illustrating the geomorphologic and ground surface conditions at the landslide site before the landslide.

The deep Zamu gully, where the present landslide occurred, was a debris-flow gully with feather-shaped branches. The gully catchment area was about $28.8 \mathrm{~km}^{2}$. The northwestern gully bank from its middle portion to its head consists of steep slopes with slope angles from $40^{\circ}$ to $90^{\circ}$. Numerous scarps, wedges, landslips and collapses were developed at the gully head zone, which indicated its instability.

A delta-shaped colluvial fan was clearly located in the Zamu gully from its lower portion to its mouth. This fan occupied a plan area of $3.4 \mathrm{~km}^{2}$. This finding indicated that landslides and debris-flows had previously taken place in the Zamu gully. The fan had a thick cover of vegetation and deeply cut stream channels, which may indicate that the debris flows and landslides in the gully had not been active in recent years.

Furthermore, a huge area of landslide debris, the Jazhong landslide, can be observed on the adjacent region southeast of the Zamu gully. The Jazhong landslide occurred in 1900 and blocked the Yi Gong River (NFCHC 2000). It is estimated that the Jazhong land- slide might have a size of $1000000000 \mathrm{~m}^{3}$. The satellite image analysis indicated that the displacement mode of the Jazhong landslide was planar sliding. Four sliding terraces and associated back-scar slopes were evident on the Jazhong landslide debris, which may indicate that further landslips had occurred in the Jazhong landslide debris.

The Xianglong gully is located opposite the Zamu gully and on the southern side of the Lower Yi Gong River. It is also a debris flow gully with a major dendritic stream system. The gully catchment area is about $65.5 \mathrm{~km}^{2}$. Its middle to upper part features numerous glacial landslides. Debris flows from the gully tributaries were well developed. Debris flows had built a $6 \mathrm{~km}^{2}$ colluvial fan at the gully mouth. This deposit had caused the relocation of the Lower Yi Gong River channel to the mouth of the Zamu gully.

From the satellite image analysis, it has become evident that the Zamu gully and the Xianglong gully have experienced several major landslides and associated debris flows during the last century. These landslide and 


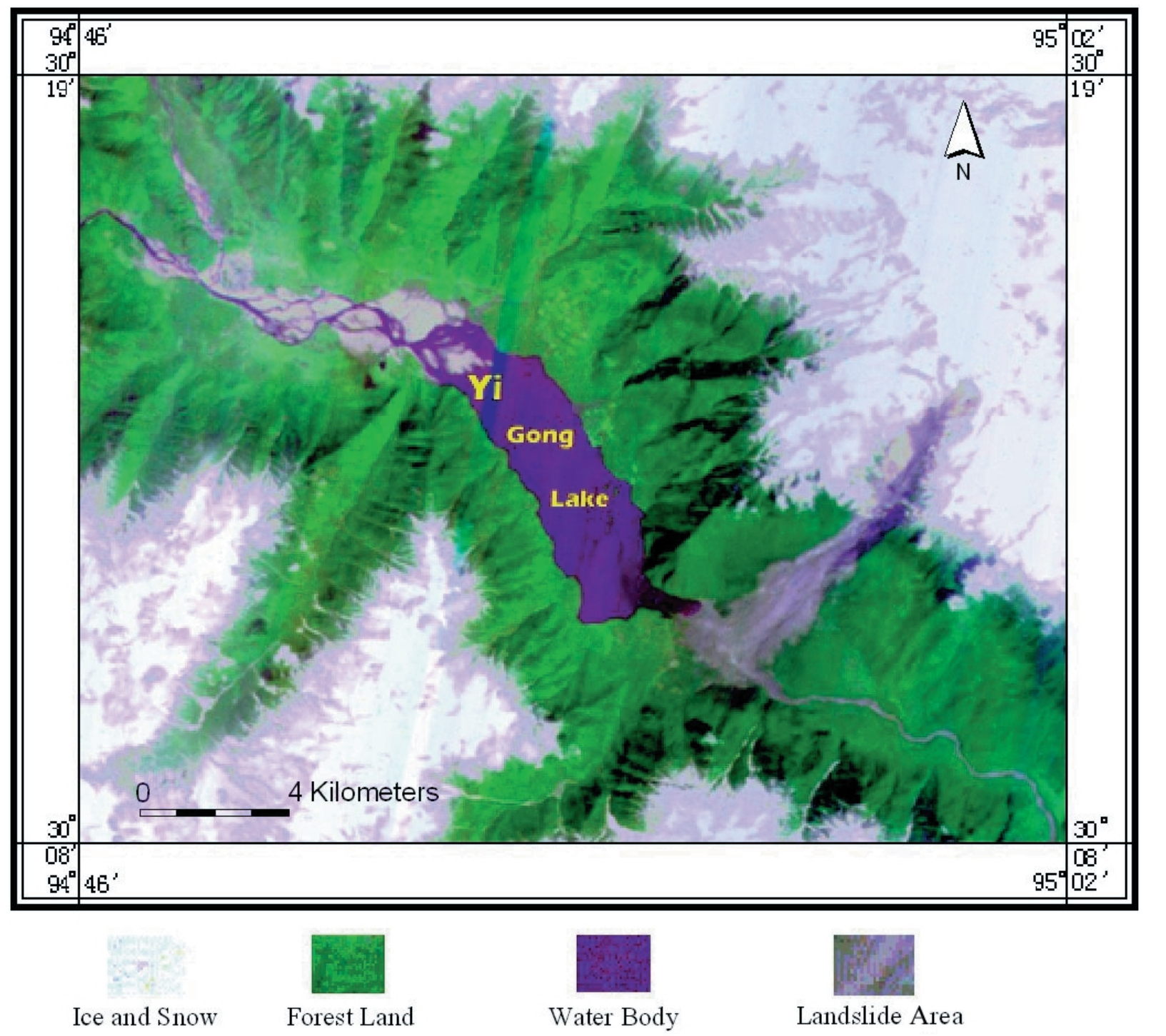

Fig. 4. The CBRS image captured on the 13 April 2000 illustrating the site conditions four days after the landslide had occurred.

debris flow incidents were the main cause of the formation of the Yi Gong Lake due to the blocking of the Lower Yi Gong River.

\section{The Yi Gong landslide}

Figure 4 presents the image obtained by processing the remote sensing data from the China-Brazil Environment and Resource Satellite No.1 captured on the 13 April 2000. This figure illustrates the site conditions four days after the landslide had occurred.

The Yi Gong landslide was clearly located at the Zamu gully. The landslide debris was in a semi-fluid condition. The landslide had a total surface area of $12.9 \mathrm{~km}^{2}$ and had a clear boundary of landslide debris and back-scar areas with the surrounding land covered by ice, snow, water and vegetation. Four different zones of the landslide are identified below, as shown in Figure 5.
- Zone I: Zone of depletion, where rock and soil slipped down and landslide back-scar is located covered with snow and ice.

- Zone II: Zone of relatively thin landslide debris on the gully center and exposed margins along the Zamu gully due to cutting and erosion by rapid sliding movement of landslide bodies and the associated high-speed and high-pressure air flow.

- Zone III: Zone of relatively thick landslide debris with high water and air content, where a large of amount of debris was displaced.

- Zone IV: Zone of loose accumulation, where landslide debris ran over the river and was deposited on the other bank of the river.

The dam formed by the landslide debris across the Lower Yi Gong River occupied an area of $2.5 \mathrm{~km}^{2}$. Field inspection found that the debris dam had heights of $55 \mathrm{~m}$ and $90 \mathrm{~m}$ on the up and down stream faces, respectively. 


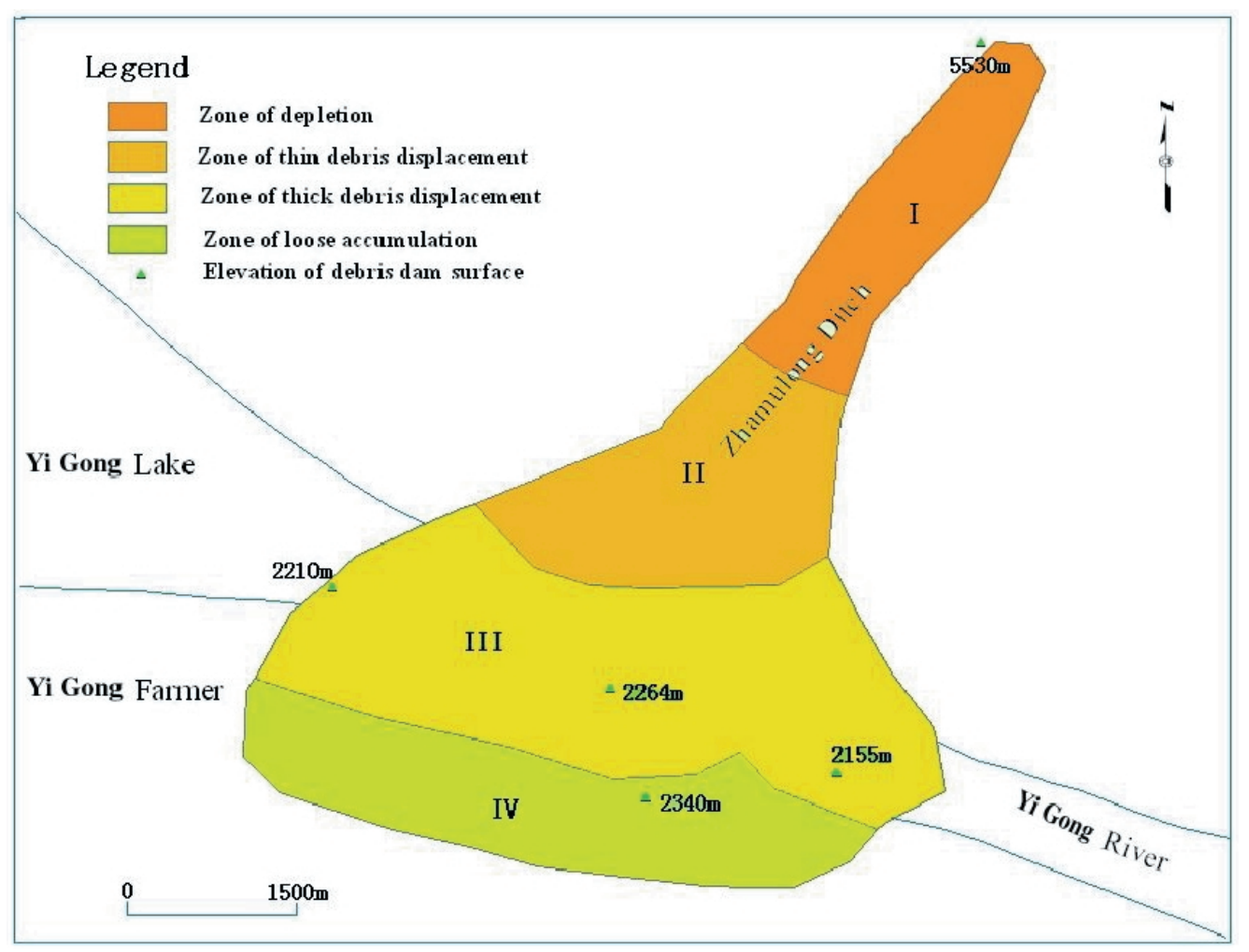

Fig. 5. Planar diagram illustrating the zoning of the Yi Gong landslide.

From comparison of Figure 3 and Figure 4, it can be observed that the glacier and snow in Figure 4 covered a much larger area in the upper portion of the Zamu gully and the mountain ridge regions than those in Figure 3. This indicates that the mountain regions had a much larger glacier- and snow-covered area in April 2000 than in November 1998.

Furthermore, the landslide blocked the Lower Yi Gong River and resulted in a rapid rise in the water level of the Yi Gong Lake basin. Five days after the landslide, more than $50 \%$ of the Yi Gong Lake basin was full of water. The flooded area in the basin was about $15 \mathrm{~km}^{2}$.

Figure 6 presents the image obtained by processing the sensing data from the French SPOT Satellite captured on the 4 May 2000. This figure illustrates the site conditions 26 days after the landslide had occurred.

The landslide was clearly visible in the image in Figure 6 and had a shape closely similar to that shown in Figure 4. However, there were some changes in Zone 1 of the landslide. The most northern boundary area of the landslide back-scar was covered with snow and ice. The exposed area of the landslide was reduced to about $11.4 \mathrm{~km}^{2}$.

On 4 May 2000, the Yi Gong Lake basin was full of water. The flooded area in the basin was about $34.7 \mathrm{~km}^{2}$.

Figure 7 presents the image obtained by processing the sensing data from the China-Brazil Environment and Resource Satellite No. 1 captured on the 9 May 2000. This figure illustrates the site condition 30 days after the landslide.
The landslide was also clearly visible in the images and had a shape closely similar to that shown in Figure 6. The exposed area of the landslide was about $12.4 \mathrm{~km}^{2}$.

The water level in the Yi Gong Lake basin continued to rise. The flooded area in the basin increased to about $37.1 \mathrm{~km}^{2}$. The increase in the flooded area in the basin was about $2.4 \mathrm{~km}^{2}$ over the five days between 4 and 9 May 2000, which indicated that the basin water level was rising quickly.

The Lower Yi Gong River below the landslide debris dam had a much reduced flow of water five days after the landslide (Figs $3 \& 4$ ). The amount of water in the Lower Yi Gong River had increased significantly 26 days after the landslide (Fig. 6). It had further increased by the 30th day when the amount of water in the Lower Yi Gong River was even more than that recorded on 28 November 1998. Furthermore, from the 26 th day to 30 th day after the occurrence of the landslide, the river colour below the debris dam had changed from that of the water in the lake, to one similar to the landslide debris.

The above observations from the images indicated that the water accumulated in the lake was seeping through the landslide debris dam and the amount of water seepage was increasing with the rise of the lake water level. The landslide debris dam was in a loose state. The volume of seepage water entering the stream became progressively larger, carrying increasing amounts of loose soil and rock along the river. 




Fig. 6. The SPOT image captured on 4 May 2000 illustrating the site conditions 26 days after the landslide had occurred.

In the evening of 11 June 2000, the landslide debris dam suddenly broke and collapsed. The large amount of the water accumulated in the Yi Gong Lake basin quickly flowed down the Lower Yi Gong River. The main river channel was widened four to five times the normal channel width. The Tongmai bridge at about $17 \mathrm{~km}$ down the debris dam across the Lower Yi Gong River and a $4.5 \mathrm{~km}$ long section of the Qinghai-Tibetan Highway were completely destroyed by the flooding. It was also reported that the sudden release of the large volume of water in the lake also caused major flooding in the floodplain area in India down the stream.

Figure 8 presents the image obtained by processing the sensing data from the French SPOT Satellite captured on the 16 June 2000. This figure illustrates the site conditions 5 days after the landslide debris dam collapsed. The main stream channel in the Lower Yi Gong River below the collapsed debris dam had the same colour as that of the water in the remaining lake. Furthermore, a detailed analysis of this image revealed that more than 20 landslips had occurred on the Lower Yi Gong River.

\section{Summary}

Based on the above satellite image analysis and the available geological data for the Yi Gong region, we can summarize the process and characteristics of the Yi Gong landslide as follows:

(1) The Yi Gong landslide was one of the major gravityinduced erosion events related to the geomorphological and tectonic evolution of the region during the present Himalayas cycle of tectonic movement. The landslide was characterized by the high-speed sliding of broken rock and debris flow. The landslide process can be described as follows:

- Initially, a major landslide occurred in the watershed zone around the Zamu gully head region due to ice and snow loading and melting.

- This landslide caused the unstable rock slopes in the upper gully to slide and collapse.

- The collapsed and crushed debris with extremely high and accelerating speed ran down the steep middle and upper gully. 


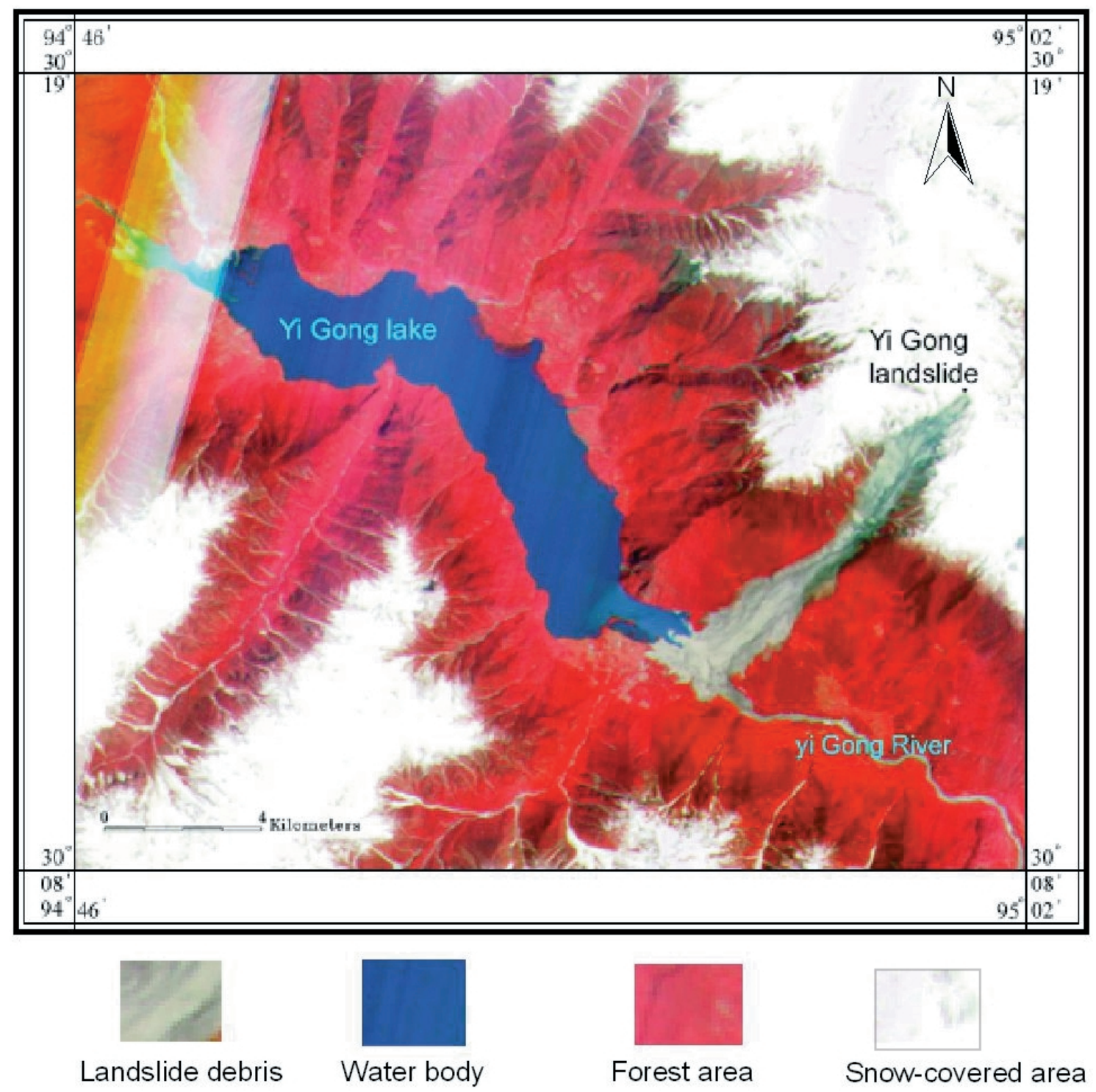

Fig. 7. The CBRS image captured on 9 May 2000 illustrating the site conditions 30 days after the landslide had occurred.

- Upon reaching the lower gully, the high-speed debris met with the previously deposited loose colluvial deposits and pushed them downslope. The volume of the sliding debris grew quickly, resulting in a gradual slowing down of the debris.

- The enlarged mass of landslide debris continued to run downslope until its leading edge crossed the Lower Yi Gong River, and continued for about $2.0 \mathrm{~km}$ over the colluvial fan at the mouth of the Xianglong gully located opposite the Zamu gully, on the other side of the river.

- Consequently, a landslide debris dam occupying an area of $2.5 \mathrm{~km}^{2}$ and with a height 55 to $90 \mathrm{~m}$ was formed on the Lower Yi Gong River.

(2) The Yi Gong landslide was about $8.0 \mathrm{~km}$ long, measured from its initiation point at the Zamu gully head to its leading edge on the colluvial fan of the
Xianglong gully. The landslide debris occupied a length of more than $5 \mathrm{~km}$. The landslide can be divided into four zones from top to bottom as follows:

- The landslide and collapse zone: which extended from the original Zamu gully head to the unstable slopes in the upper gully, where the crushed debris was generated (the upper Zone I in Fig. 5).

- The debris flow accumulation and acceleration zone: the steepest, deepest, narrowest and most conspicuous portion of the Zamu gully, where the debris from the landslip and collapse zone accumulated and accelerated (the lower Zone I in Fig. 5).

- The main debris flow movement and enlargement zone: where the accelerated landslide debris pushed the previously deposited loose debris in the gully bed downslope, scouring the ground surface along its path (the Zone II in Fig. 5). 


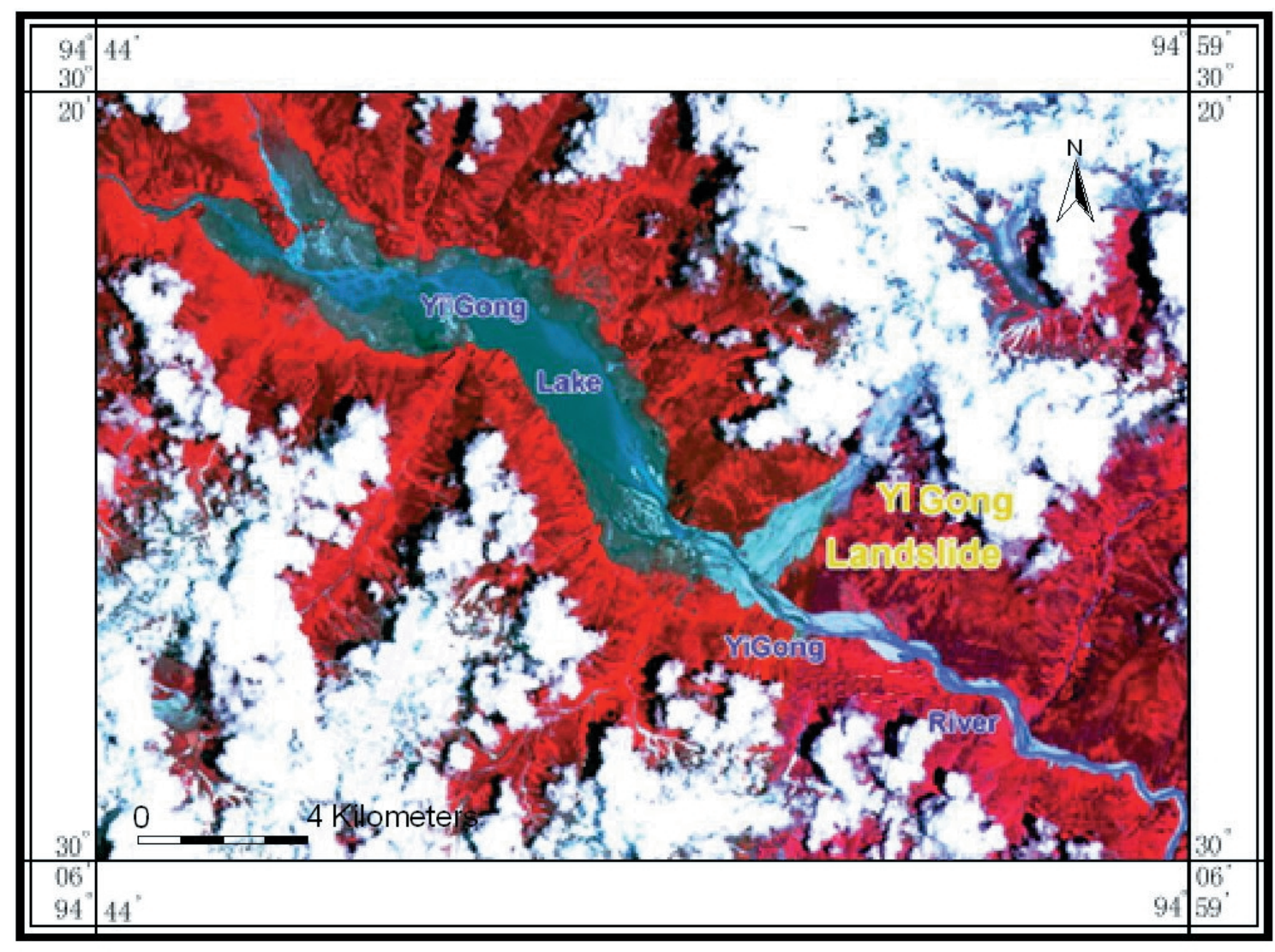

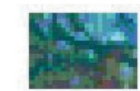

Flooded Area Cloud-covered Area

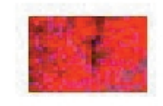

Forest Land

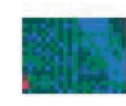

Water Body Landslide Spot

Fig. 8. The SPOT image captured on 16 June 2000 illustrating the site conditions five days after the landslide debris dam collapsed.

- The debris deposit zone: which extended from the gully mouth to the debris far front end on the colluvial deposit in the Xianglong gully mouth, where the landslide debris dam was located (the Zones 3 and 4 in Fig. 5).

(3) The landslide debris dam completely blocked the Lower Yi Gong River, turning the Yi Gong Lake basin into a large body of water with a surface area of more than $37 \mathrm{~km}^{2}$ within 30 days. The water trapped in the temporary lake soon started seeping through the very loose debris dam, and the amount of seepage increased quickly as the lake level rose. An increasing amount of loose soil and rock in the debris dam was carried along by the seepage water down the river, as a result of piping. Eventually, because of the relatively high head of water in the lake and the increasing seepage, the dam collapsed 63 days after the landslide.

The collapse of the dam caused a large amount of the lake water to flow suddenly down the Yi Gong
River. The large volume of lake water flowing down the river destroyed a $4.5 \mathrm{~km}$ long section and the Tongmai bridge of the Qinghai-Tibetan Highway, caused more than 20 landslips on the Lower Yi Gong River and major flooding of the floodplain in India.

\section{References}

Manotvani, F., Soeters, R. \& van Westen, C. J. 1996. Remote sensing techniques for landslide studies and hazard zonation in Europe. Geomorphology, 15, 213-225.

McDonald, H. C. \& GrubBs, R. C. 1975. Landsat imagery analysis: an aid for predicting landslide prone areas for highway construction Proceedings of NASA Earth Resources Symposium, Houston, Texas, 1b, 769-778.

NFCHC, 2000. Report on Landslide Survey in the Yi Gong District. National Flood Control Headquarter of China (NFCHC), Beijing, China.

Xu, X., WeI, Z-S., CHEN, G-E. \& JiAO, S-R. 1982. Stratigraphic Scale in Tibet Plateau Region. Geological Press of China, Beijing, China. 